\title{
Serratospiculosis in a wild peregrine falcon (Falco peregrinus) from the Cerrado region, Minas Gerais, Brazil
}

Serratospiculose em um falcão-peregrino selvagem (Falco peregrinus) da região do Cerrado, Minas Gerais, Brasil

\author{
Wilson Junior Oliveira (1) ${ }^{1 *}$ \\ Nathana Beatriz Martins (D) ${ }^{2}$ \\ Nataly Nogueira Ribeiro Pinto (D) ${ }^{2}$ \\ Fernanda Rosalinski-Moraes (1) ${ }^{2}$ \\ Estevam Guilherme Lux Hoppe (D) ${ }^{1}$
}

\author{
1 Universidade Estadual Paulista (UNESP), Jaboticabal, SP, Brazil \\ ${ }^{2}$ Universidade Federal de Uberlândia (UFU), Uberlândia, MG, Brazil \\ *Correspondence: wilsonjr2009@hotmail.com \\ Received: 2020 Sep 2 | Approved: 2021 Jan 27 \\ DOI: http://dx.doi.org/10.7213/acad.2021.19202 \\ Rev. Acad. Ciênc. Anim. 2021;19:e19202
}

Research Laboratory, at the Universidade Federal de Uberlândia, Minas Gerais, Brazil. The bird was unable to fly and was in poor health condition. A clinical examination revealed severe dehydration, complete carpometacarpal fracture in the left wing, confirmed by radiography, and wheezing upon auscultation of the lungs and air sacs. To confirm a possible parasitic infection of the air sacs, an endoscopic examination was performed. Two nematodes were retrieved from the right abdominal air sac, and one identified as Serratospiculum sp. based on the distinctive epaulettes representative of this genus. Even with a low parasite burden, the bird presented characteristic clinical signs that can be associated, either directly or indirectly, with Serratospiculum sp. infection. Despite this, more studies are needed to evaluate the unknown clinical aspects of this disease.

Keywords: Air sacs. Falconiformes. Nematode. Serratospiculum sp. 


\section{Resumo}

Serratospiculum spp. são parasitas comuns dos sacos aéreos dos Falconiformes. O objetivo deste estudo foi relatar um caso de infecção por Serratospiculum sp. em um falcão-peregrino adulto (Falco peregrinus). Em fevereiro de 2020, uma fêmea adulta de falcãoperegrino foi encontrada em uma área urbana no município de Uberlândia e as autoridades ambientais a levaram para o Laboratório de Pesquisa da Vida Selvagem, da Universidade Federal de Uberlândia, Minas Gerais, Brasil. O pássaro não conseguia voar e estava em más condições de saúde. O exame clínico revelou desidratação grave, fratura completa do carpometacarpo na asa esquerda, confirmada por radiografia, e sibilância à ausculta pulmonar e de sacos aéreos. Para confirmar uma possível infecção parasitária dos sacos aéreos, realizou-se um exame endoscópico. Dois nematóides foram recuperados do saco aéreo abdominal direito e um foi identificado como Serratospício sp. com base nas dragonas distintas representativas deste gênero. Mesmo com baixa carga parasitária, a ave apresentava sinais clínicos característicos que podem estar associados, direta ou indiretamente, à infecção por Serratospiculum sp. Apesar disso, mais estudos são necessários para avaliar os aspectos clínicos desconhecidos desta doença.

Palavras-chave: Sacos de ar. Falconiformes. Nematode. Serratospiculum sp.

\section{Introduction}

Nematodes of the genus Serratospiculum (Skrjabin, 1915) are common parasites of the air sacs of birds, particularly those of the order Falconiformes. These parasites may cause serious complications in their hosts, including fatal pneumonia, even after the hosts receive treatment (Königová et al., 2013).

Like other spirurids, Serratospiculum spp. are heteroxenous, using coprophagous beetles, grasshoppers, woodlice, and locusts as intermediate hosts and birds as a definitive host (Bain and Vassiliades, 1969; Veiga et al., 2017). The adult worms lay their embryonated eggs in the air sacs of birds, which are then passed through the lungs, and then coughed up and swallowed, eventually reaching the digestive system where they are eliminated via bird droppings. The intermediate arthropod hosts ingest these eggs, and the larvae hatch and molt until the third infective stage (L3) within the adipose tissue of the hosts. Avian hosts feed on these arthropods, and in turn get infected with this infective larvae, which migrate from the proventriculus directly to the air sacs, where they attaining sexual maturity (Santoro et al., 2016; Van Wettere et al., 2018).

The genus Serratospiculum is comprised of nine species that have been identified in America, Africa, Australia, New Zealand, Asia, Middle East, and Europe. In South America, there have been three reports of nematodes of this genus infecting birds of prey. The first case described $S$. verrucosum infection of a Swainson's hawk (Buteo swainsoni) in Brazil (Molin, 1858), while the other two cases described Serratospiculum tendo infection in a peregrine falcon from Peru (Gomez-Puerta et al., 2014), and an Austral peregrine falcon (Falco peregrinus cassini) from Argentina (Ibarra et al., 2019). However, little information is available for the helminth fauna of Falco peregrinus, with only a few reports of infection with strigeid digenean species, filariids, ascarids, and tapeworms (Santoro et al., 2012).

The objective of this study was to report a case of Serratospiculum sp. infection in a peregrine falcon (Falco peregrinus) found in Uberlândia, Minas Gerais State, Brazil. To the best of our knowledge, this is the first formal case description of this nematode in Falco peregrinus in Brazil, thus expanding its geographic range within South America.

\section{Case report}

In February 2020, environmental authorities brought an adult female peregrine falcon weighing $920 \mathrm{~g}$ to the Wild Animal Research Laboratory (LAPAS), at the Universidade Federal de Uberlândia. The bird was found in an urban area of municipality of Uberlândia on the ground and unable to fly. The animal was alert, responsive to stimulus, and had a good body condition ( 3 on a scale from 1 to 5) (Harrison and Lightfoot, 2005). Upon physical examination, severe dehydration, wheezing in the air sacs, and crackles in the distal portion of the left wing were noted. After several weeks of captivity, white plaques were observed in the oral 
cavity and were confirmed to be Trichomonas spp. by microscopic examination. Treatment consisted of 15 $\mathrm{mg} / \mathrm{kg}$ metronidazole once in a day for five days, with complete recovery. Three serial fecal screens were performed and all the exams were negative.

Radiography revealed complete carpometacarpal fracture of the left wing. The bird was treated with $20 \mathrm{~mL} / \mathrm{kg} / \mathrm{d}$ fluid therapy (Ringer's Lactate), $0.6 \mathrm{~mL} /$ $\mathrm{kg}$ B vitamin complex (Bionew $\left.{ }^{\circledR}\right), 10 \mathrm{mg} / \mathrm{kg}$ tramadol hydrochloride and $2 \mathrm{mg} / \mathrm{kg}$ meloxicam, and the wing was placed in a bone splint for 14 days to facilitate fracture healing. Following treatment reevaluation, the bird showed permanent wheezing in the air sacs.

A second round of radiography showed an increased density in the abdominal air sacs (Figure 1), and an endoscopy was performed to rule out parasitic air sac infection. The bird was anesthetized with $10 \mathrm{mg} / \mathrm{kg}$ ketamine, $1 \mathrm{mg} / \mathrm{kg}$ midazolam and induced with isoflurane. A $2.9 \mathrm{~mm}$ zero-degree endoscope (Tonglu Wanhe) was used to examine all the air sacs. The right abdominal air sac was mildly thickened and opaque, and two nematodes were found inside the air sac and removed. The falcon died following the endoscopy and the necropsy confirmed the endoscopic findings.

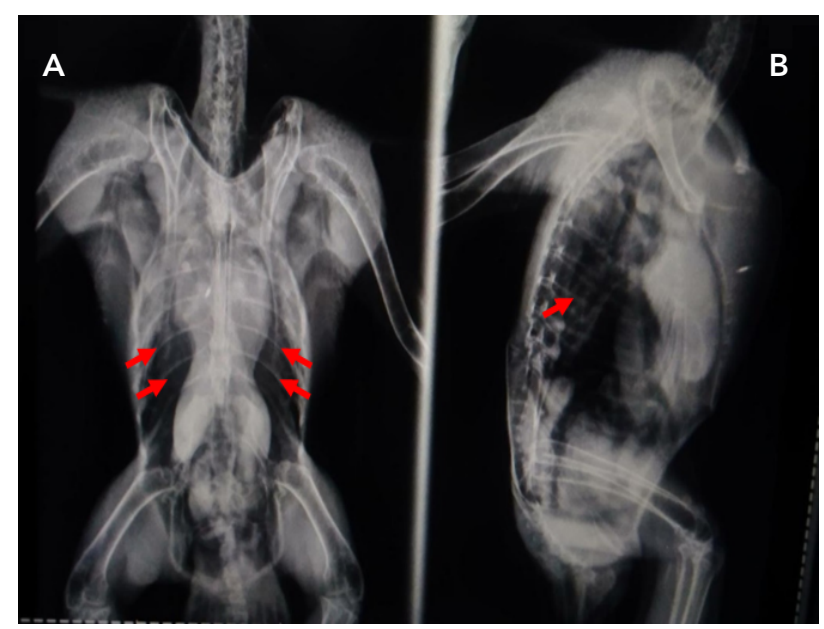

Figure 1 - Peregrine falcon radiography. Ventrodorsal (A) and lateral (B) radiographic view showing opacity in the abdominal air sacs (red arrows).

One of the nematodes retrieved was fixed in 10\% formalin and sent to the Parasitic Diseases Laboratory (LabEPar), Universidad Estadual Paulista (UNESP),
Campus Jaboticabal, for taxonomic assessment. The specimen was clarified in $80 \%$ acetic acid and identified according to the classification key proposed by Vicente et al. (1995), and based on research findings by Yoshino et al. (2014) and Ibarra et al. (2019). Images and morphometric data were obtained with an Olympus BX-51 microscope attached to a QColor 3 camera (Olympus, Tokyo, Japan) and processed using Image Pro Plus v. 4.0 software. Based on the morphologic aspects described below, the adult helminth was identified as a female of the genus Serratospiculum.

\section{General description}

Filariform parasite, whitish in color, measuring $265 \mathrm{~mm}$ in length. Oral opening composed of trilobated and prominent lips. Nerve ring and excretory pore $0.42 \mathrm{~mm}$ and $0.20 \mathrm{~mm}$ from the anterior end, respectively. The length of esophagus could not be accurately measured due to an overlap with an egg-filled uterus. Cephalic formations were epaulette-like on the lateral view. Vulvar opening was $1.03 \mathrm{~mm}$ from the anterior end of the body. Thick shelled, embryonated eggs, measuring $0.047 \mathrm{~mm}$ long and $0.03 \mathrm{~mm}$ wide, were present in the uterus. Subterminal anus, $0.06 \mathrm{~mm}$ from the posterior extremity. Rounded tail, as seen in Figures 2 and $3 A, B$.

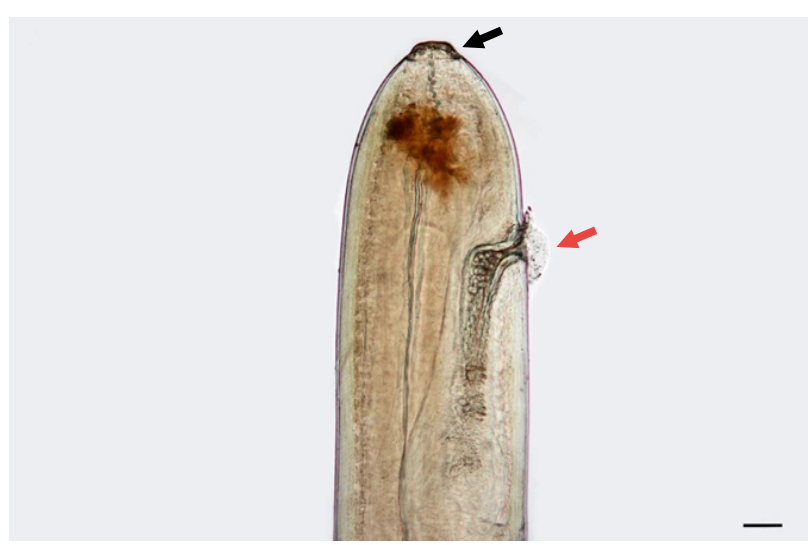

Figure 2 - Microscopic feature of Serratospiculum sp. recovered from a peregrine falcon (Falco peregrinus) in the municipality of Uberlândia, Minas Gerais, Brazil. A female anterior extremity showing trilobated lips (black arrow) and vulvar opening (red arrow). Magnification: 40 x; Scale bar: $1000 \mu \mathrm{m}$. 

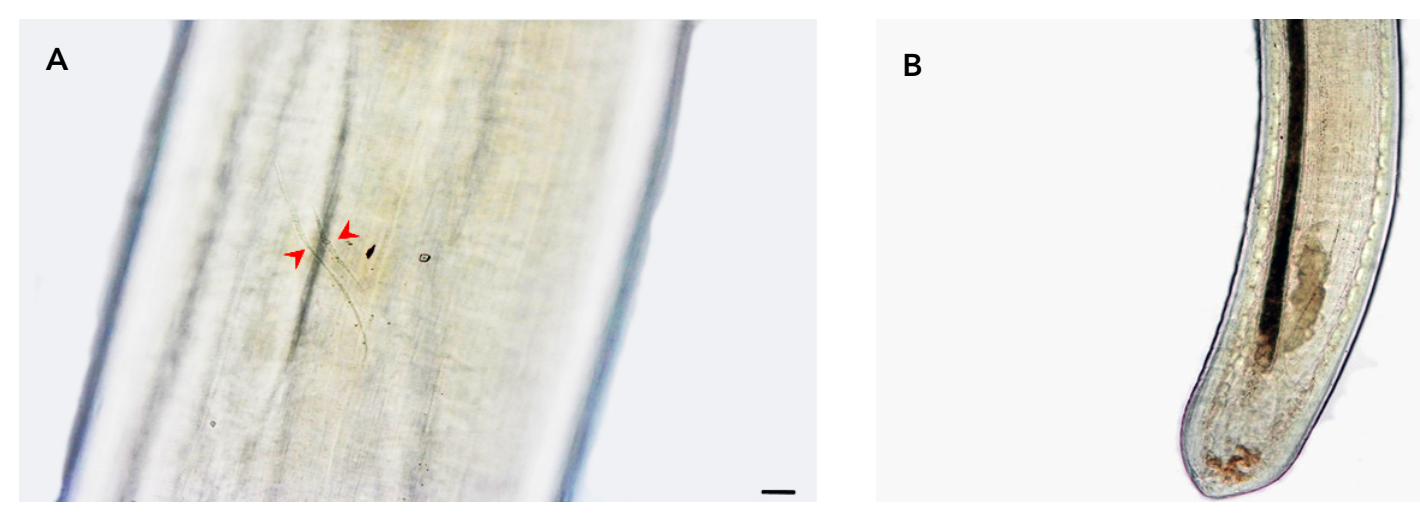

Figure 3 - Microscopic features of Serratospiculum sp. recovered from a peregrine falcon (Falco peregrinus) in the municipality of Uberlândia, Minas Gerais, Brazil. (A) Lateral view, showing the genus characteristic epaulettes (red arrow heads). Magnification: 100x; Scale bar: $50 \mu \mathrm{m}$. (B) Female caudal gland at the tip of a rounded tail. Magnification: 40x; Scale bar: $1000 \mu \mathrm{m}$.

\section{Discussion}

Morphological and morphometric analysis of the lips and vulvar opening at the anterior region, and the presence of epaulettes, can be used to easily classify nematodes in the genus Serratospiculum (Vicente et al., 1995). Species-specific identification is based on male spicule characteristics (Bain and Mawson, 1981); however, this was not possible in the present study as a male nematode was not retrieved. Nevertheless, considering the distribution of Serratospiculum species in South America, this falcon was likely infected with Serratospiculum tendo (Ibarra et al., 2019).

Despite their carnivorous feeding habits, falcons are frequently observed eating insects that roam around their perches, mainly during periods of the day when these arthropods are most active (Samour and Naldo, 2001). This feeding behavior can contribute to their infection by Serratospiculum species. As the diet of peregrine falcons is almost entirely composed of small and medium-sized birds, it has been suggested that these animals can act as paratenic hosts for this nematode infection (Santoro et al., 2016).

Serratospiculosis in raptors can range from mild to severe, in some cases leading to death, or justification for euthanasia (Van Wettere et al., 2018). Dyspnea, lethargy, pneumonia, difficulty in flying, pharyngeal plaques, and vomiting are the most common clinical signs (Samour and Naldo, 2001; Santoro et al., 2016). The pathogenicity of this nematode is still uncertain, however the parasite burden may be associated with the severity of clinical manifestations (Königová et al., 2013). Bigland et al. (1964) reported five cases of Serratospiculum amaculata infection in prairie falcons (Falco mexicanus) from Canada, involving several worms tangled in the abdominal and thoracic air sacs, associated with severe cachexia and dehydration of the hosts. Santoro et al. (2010) reported similar signs in peregrine falcons and a northern goshawk from Italy, infected with 10 or more Serratospiculum tendo adults. Contrary to these studies, Samour and Naldo (2001), reported that there was no correlation between a high parasitic load and drop in hunting or training performance in falcons, which suggests a well-established host-parasite relationship.

In our study, despite retrieving only two helminths, the peregrine falcon presented signs of respiratory illness including wheezing upon auscultation of the air sacs as well as thickening and opacity of the affected air sac. Veiga et al. (2017) showed that adult Serratospiculum species can survive for many years within the air sacs causing alterations in the tissues of this organ and compromising air circulation. The severe dehydration of the falcon reported in this study is more likely due to a decrease in food intake owing to its fractured left wing, which restricted its ability to search for food. More studies are needed to evaluate the extension and further consequences of this parasitic disease in their hosts. 
Fractures, as observed in this case, have previously been reported in falcons infected with Serratospiculum spp. It has been suggested that increased trauma in birds infected with Serratospiculum could be due to the resulting poor health condition or an imbalance due to the presence of nematodes in the air sacs (Santoro et al., 2016; Ibarra et al., 2019). Considering the size of the air sac, and that the organ was almost entirely filled with helminths, perhaps the falcon in this case had a flight imbalance, which led to a crash ultimately causing the observed bone fracture. Despite this, the clinical consequences of Serratospiculum tendo, the species likely observed in this report, is still unknown (Santoro et al., 2016) and further investigations are required.

\section{Conclusion}

It was noted that the falcon in this report, even with a low parasite burden, presented clinical manifestations that can be secondarily or directly related to parasitism by Serratospiculum sp. We would like to emphasize the necessity for continuous monitoring of avian hosts, as well as the retrospective analysis of previous research, to fully understand the undefined aspects of serratospiculosis.

\section{References}

Bain O, Mawson PM. Oviparous filarial nematodes mainly from Australian birds. Rec S Aust Mus. 1981;18:265-84.

Bain O, Vassiliades G. Cycle évolutif d'un Dicheilonematinae, Serratospiculum tendo, Filaire parasite du faucon. Ann Parasitol Hum Comp. 1969;44(5):595-604.

Bigland CH, Liu SK, Perry ML. Five cases of Serratospiculum amaculata (Nematoda: Filaroidea) infection in prairie falcons (Falco mexicanus). Avian Dis. 1964;8(3):412-9.

Gomez-Puerta LA, Ospina PA, Ramirez MG, Cribillero NG. Primer registro de Serratospiculum tendo (Nematoda: Diplotriaenidae) in Peru. Rev Peru Biol. 2014;21(1):111-4.

Harrison GJ, Lightfoot T. Clinical avian medicine. Palm Beach: Spix Publishing; 2005. 1008 p.
Ibarra J, Sierra RLMY, Neira G, Ibaceta DEJ, Saggese MD. Air Sac Nematode (Serratospiculum tendo) Infection in an Austral Peregrine Falcon (Falco peregrinus cassini) in Argentina. J Wildl Dis. 2019;55(1):179-82.

Königová A, Molnár L, Hrčková G, Várady M. The first report of serratospiculiasis in Great Tit (Parus major) in Slovakia. Helminthologia. 2013;50(4):254-60.

Molin R. Versuch einer Monographie der Filarien. Verl Bayer akad wiss. 1858;28(5):365-461.

Samour JH, Naldo J. Serratospiculiasis in captive falcons in the Middle East: A review. J Avian Med Surg. 2001;15(1):2-9.

Santoro M, D'Alessio N, Di Prisco F, Kinsella JM, Barca L, Degli Uberti $B$, et al. The occurrence and pathogenicity of Serratospiculum tendo (Nematoda: Diplotriaenoidea) in birds of prey from southern Italy. J Helminthol 2016;90(3):294-7.

Santoro M, Kinsella JM, Galiero G, Degli Uberti BD, Aznar FJ. Helminth community structure in birds of prey (Accipitriformes and Falconiformes) in Southern Italy. J Parasitol. 2012;98(1):22-9.

Santoro M, Tripepi M, Kinsella JM, Panebianco A, Mattiucci S. Helminth infestation in birds of prey (Accipitriformes and Falconiformes) in southern Italy. Vet J. 2010;186(1):119-22.

Skrjabin KJ. Nematodes des oiseaux du Turkestan russe. Annu Mus Zool Acad IMP Sci St Petersb. 1915;20:457-557.

Van Wettere AJ, Kurz JP, Wilhelm A, Ipsen JD. Opisthotonos and unilateral internal hydrocephalus associated with aberrant migration of Serratospiculum sp. or Serratospiculoides sp. in a prairie falcon. J Vet Diagn Invest. 2018;30(5):770-3.

Veiga IB, Schediwy M, Hentrich B, Frey CF, Marreros $N$, Stokar-Regenscheit N. Serratospiculosis in captive peregrine falcons (Falco peregrinus) in Switzerland. J Avian Med Surg. 2017;31(3):250-5.

Vicente JJ, Rodrigues HO, Gomes DC, Pinto RM. Nematóides do Brasil. Parte IV: nematóides de aves. Rev Bras Zool. 1995;2(Suppl:1):1-273.

Yoshino T, Hama N, Onuma M, Takagi M, Sato K, Matsui $S$, et al. Filarial nematodes belonging to the superorders Diplotriaenoidea and Aproctoidea from wild and captive birds in Japan. J Rakuno Gakuen Univ. 2014;38(2):139-48. 